\title{
Effects of Thyroid Hormone on Sodium Pump Sites, Sodium Content, and Contractile Responses to Cardiac Glycosides in Cultured Chick Ventricular Cells
}

Donghee Kim and Thomas W. Smith

Cardiovascular Division, Brigham and Women's Hospital, and Department of Medicine, Brigham and Women's Hospital and Harvard Medical School, Boston, Massachusetts 02115

bstract. Sensitivity of cardiac muscle to digitalis glycosides depends on the thyroid state. The mechanism of this interaction was investigated at the cellular level using spontaneously beating monolayers of cultured chick embryo ventricular cells. Cells were grown for 48 $h$ in serum-free medium containing concentrations of triiodothyronine $\left(\mathrm{T}_{3}\right)$ from zero to $10^{-7} \mathrm{M}$, and the total number of sodium pump sites, sodium content, and contractile amplitude in the presence and absence of various concentrations of ouabain were determined. $T_{3}$ caused a concentration-dependent increase in the number of specific ouabain binding sites; the maximal increase to $160 \%$ of control was observed in response to $10^{-8} \mathrm{M}$ $T_{3} . T_{3}$ lowered steady-state cellular sodium content in a concentration-dependent manner, also. Ouabain (1 $\mu \mathrm{M})$ exposure elevated cellular sodium content in all cells, but the increase was greatest in cells grown in $\mathrm{T}_{3^{-}}$ free medium and least in cells grown in $10^{-8} \mathrm{M} \mathrm{T}_{3}$. The positive inotropic and toxic effects of ouabain in cells grown in $10^{-8} \mathrm{M} \mathrm{T} \mathrm{T}_{3}$ were diminished at any given ouabain concentration, and thus, the dose-response curve was shifted to the right. These results indicate that $T_{3}$ causes induction of additional sodium pump sites that are functional. The increased tolerance of hyperthyroid cells and reduced tolerance of hypothyroid cells to cardiac glycosides can be explained by these changes in the number of sodium pump sites and cellular sodium

Address correspondence to Dr. Kim, Cardiovascular Division, Brigham and Women's Hospital, Boston, MA 02115.

Received for publication 24 January 1984 and in revised form 31 May 1984.

J. Clin. Invest.

(c) The American Society for Clinical Investigation, Inc.

$0021-9738 / 84 / 10 / 1481 / 08 \quad \$ 1.00$

Volume 74, October 1984, 1481-1488 content, and consequently, calcium influx via sodiumcalcium exchange.

\section{Introduction}

Changes in thyroid state have been well documented to affect the sensitivity of the heart to digitalis glycosides. Thus, hyperthyroidism and hypothyroidism are associated with increased and decreased tolerance, respectively, to the cardiac effects of digitalis (1-3). The mechanism of altered digitalis sensitivity has been attributed in part to changes in pharmacokinetic disposition of glycosides, since significantly higher serum levels of glycosides were found in patients with hypothyroidism than in patients with hyperthyroidism following administration of identical doses $(4,5)$. These differences in serum levels of cardiac glycosides appear to be accounted for by changes in distribution volume and in renal clearance (5-7). However, Kokenge et al. (8) observed no significant differences in serum digitoxin levels between hypo- and hyperthyroid patients receiving similar doses. Furthermore, it is a common clinical experience to find the ventricular rate of thyrotoxic patients with atrial fibrillation difficult to control, despite relatively large doses and high serum concentrations of digoxin. Thus, the fundamental basis for the influence of thyroid status on cardiac glycoside effects remains incompletely understood.

At the cellular level, thyroid hormone has been shown to increase NaK-ATPase activity (9-11) and the number of NaKATPase complexes in several types of tissues (12-15). If other properties of myocardial cells remained constant, we would expect such changes in the number of sodium pump sites or sodium pump activity to alter intracellular sodium content, and hence, sodium-calcium exchange across sarcolemmal membranes (16-19). We have previously shown that cardiac glycosides cause elevation of intracellular sodium content in cultured chick ventricular cells, and that this increase in $\left[\mathrm{Na}^{+}\right]_{\mathbf{i}}$ is associated with an increase in rapidly exchangeable cellular $\mathrm{Ca}^{++}$and the increased contractile state associated with enhanced $\mathrm{Na}-\mathrm{Ca}$ exchange $(20,21)$. In cardiac tissues exposed to excessive levels of thyroid hormone, we postulate that intra- 
cellular sodium content may not be elevated to the same extent by cardiac glycosides as a result of increased sodium pump activity compared with tissues exposed to normal or low levels of thyroid hormone. If this occurs, contractile responses to positive inotropic agents that act by elevating intracellular sodium content would be expected to be reduced due to decreased calcium influx via sodium-calcium exchange $(17,19,22)$. Therefore, we used cultured chick ventricular cell monolayer preparations, for which the growth conditions can be precisely controlled, to explore the effects of graded amounts of $\mathrm{T}_{3}$ and ouabain on NaK-ATPase, intracellular sodium content, and contractile state.

\section{Methods}

Tissue Culture. Monolayer cultures of spontaneously contracting chick embryo ventricular cells were prepared as previously described (20). Briefly, hearts of 10-d-old chick embryos were removed and ventricular tissue was cut into small fragments $\left(<0.5 \mathrm{~mm}^{3}\right)$; individual cells were isolated by four cycles of trypsinization with $0.025 \%$ (wt/vol) trypsin at $37^{\circ} \mathrm{C}$. The culture medium contained $6 \%$ heat-inactivated fetal calf serum, 40\% M199 with Hanks's salts, 0.1\% penicillin-streptomycin solution, and $54 \%$ balanced salt solution. Balanced salt solution contained $116 \mathrm{mM} \mathrm{NaCl}, 1.0 \mathrm{mM} \mathrm{NaH}_{2} \mathrm{PO}_{4}, 0.8 \mathrm{mM} \mathrm{MgSO} \cdot \mathrm{H}_{2} \mathrm{O}$, $1.18 \mathrm{mM} \mathrm{KCl}, 26.2 \mathrm{mM} \mathrm{NaHCO}, 0.87 \mathrm{mM} \mathrm{CaCl}_{2}$, and $5.5 \mathrm{mM}$ glucose. The final concentrations of $\mathrm{K}^{+}, \mathrm{Na}^{+}$, and $\mathrm{Ca}^{++}$in culture medium were $4.0,137$, and $0.97 \mathrm{mM}$, respectively. The cell suspension was diluted to $5 \times 10^{5}$ cells $/ \mathrm{ml}$ and placed in plastic culture dishes $(100 \times 20 \mathrm{~mm}$ or $60 \times 15 \mathrm{~mm}$, Falcon Labware, Oxnard, CA). The larger culture dishes contained $25-\mathrm{mm}$ circular glass coverslips and were used in ion flux studies whereas the smaller dishes without coverslips were used in $\left[{ }^{3} \mathrm{H}\right]$ ouabain-binding studies. Cultures were incubated in a humidified $5 \% \mathrm{CO}_{2}: 95 \%$ air atmosphere at $37^{\circ} \mathrm{C}$. Confluent monolayers in which at least $80 \%$ of cells exhibited spontaneous synchronous contractions developed by 2-3 d of incubation.

After the cells were allowed to grow in culture medium containing $6 \%$ fetal calf serum for $48 \mathrm{~h}$, the medium was replaced with serumfree medium (23) containing $10^{-6} \mathrm{M}$ insulin, $5 \times 10^{-8} \mathrm{M}$ transferrin, $10^{-9} \mathrm{M}$ selenium, and concentrations of triiodothyronine $\left(\mathrm{T}_{3}\right)^{1}$ varying from zero to $10^{-7} \mathrm{M}$. The final concentrations of $\mathrm{K}^{+}, \mathrm{Na}^{+}$, and $\mathrm{Ca}^{++}$ in serum-free medium were identical to those in serum-containing medium. Cells continued to contract spontaneously and remained viable for at least $2 \mathrm{wk}$ in the serum-free medium.

$\left[{ }^{3} \mathrm{H}\right]$ ouabain binding. The number of sodium pump sites in the sarcolemma was estimated from $\left[{ }^{3} \mathrm{H}\right]$ ouabain binding to intact, beating cultured ventricular cells. Specific binding of $\left[{ }^{3} \mathrm{H}\right]$ ouabain was measured by modification of the methods of McCall (24) and Aiton et al. (25). Briefly, monolayers of ventricular cells attached to culture dishes were incubated in $\mathrm{K}^{+}$-free Hepes-buffered solution (pH 7.35) containing 4 mM Hepes, $0.05 \mathrm{mM} \mathrm{CaCl}_{2}, 137 \mathrm{mM} \mathrm{NaCl}, 0.5 \mathrm{mM} \mathrm{MgCl}$, and various concentrations of $\left[{ }^{3} \mathrm{H}\right]$ ouabain $(60-1000 \mathrm{nM})$ for predetermined periods of time $(0-20 \mathrm{~min})$ at $37^{\circ} \mathrm{C}$. Stock $\left[{ }^{3} \mathrm{H}\right]$ ouabain $(18 \mathrm{Ci} / \mathrm{mmol}$, New England Nuclear, Boston, MA) was diluted with unlabeled ouabain to give the desired final concentrations of $\left[{ }^{3} \mathrm{H}\right]$ ouabain. Following $\left[{ }^{3} \mathrm{H}\right]$ ouabain exposure, the cells were quickly scraped from the dish and filtered through a microfiber filter (pore size, $12 \mu \mathrm{m}$;

1. Abbreviations used in this paper: $\mathrm{T}_{3}$, triiodothyronine.
Whatman Laboratory Products, Inc., Clifton, NJ). Filters were washed three times with ice-cold Hepes-buffered solution (pH 7.35) containing $20 \mathrm{mM} \mathrm{KCl}$ and dissolved in Hydrofluor (National Diagnostics, Inc., Somerville, NJ). Radioactivity on the filter was assayed using a liquid scintillation spectrometer. Specific $\left[{ }^{3} \mathrm{H}\right]$ ouabain binding was calculated as total binding in the absence of $10^{-3} \mathrm{M}$ nonlabeled ouabain minus the value obtained in its presence, and is expressed as picomoles per milligram protein. To determine protein content on each filter, cells on the plates not exposed to $\left[{ }^{3} \mathrm{H}\right]$ ouabain were thoroughly washed to remove all $\left[{ }^{14} \mathrm{C}\right]$ leucine in the extracellular space by placing the plates in three large volumes $(50 \mathrm{ml})$ of bicarbonate buffer solution for 5 min each at $37^{\circ} \mathrm{C}$. The cells were then dissolved, and aliquots of the medium containing dissolved cells were assayed for protein content using the method of Lowry et al. (26).

Contractility measurements. Changes in the contractile state of individual cells in the monolayers were assessed by the use of an optical-video system as previously described $(20,21)$. A glass coverslip with attached monolayer of cultured cells was continuously superfused with serum-free medium at a rate of $2 \mathrm{ml} / \mathrm{min}$ in a chamber with inlet and outlet ports on the stage of an inverted phase-contrast microscope. The $\mathrm{pH}$ of the medium was maintained at 7.4 by continuously gassing the chamber with a $95 \%$ air.5\% $\mathrm{CO}_{2}$ gas mixture. A constant temperature of $37^{\circ} \mathrm{C}$ was maintained by enclosing the microscope in a thermostated Lucite box. Following a 15 -min equilibration period in control medium, cells were superfused with otherwise identical solution containing ouabain at concentrations varying from zero to $4 \mu \mathrm{M}$, and changes in the amplitude of motion of an individual cell were monitored. Only one cell from each coverslip was used and the change in the amplitude of contraction was expressed as a percent of the change observed in response to exposure to $3.6 \mathrm{mM}\left[\mathrm{Ca}^{++}\right]_{0}$, a concentration which produced a maximal contractile response in cells grown under these conditions.

Sodium content and ${ }^{42} \mathrm{~K}$-uptake. The procedures for estimating sodium content have been described in detail by Biedert et al. (20) and Barry and Smith (19). For determination of sodium content, glass coverslips with attached monolayers of cells were immersed in bicarbonate-buffered solution (pH 7.35) containing ${ }^{24} \mathrm{Na}\left(5 \mu \mathrm{Ci} / \mathrm{ml},\left[\mathrm{Na}^{+}\right]\right.$ $=143 \mathrm{mM})$ and the cells were labeled to asymptote $(30 \mathrm{~min})$. After appropriate periods of labeling with ${ }^{24} \mathrm{Na}$, cells were washed twice for $8 \mathrm{~s}$ each by gently agitating the glass coverslips sequentially in two 60 $\mathrm{ml}$ volumes of ice-cold balanced salt solution containing no radioisotope. The cells were then dissolved in medium containing $1 \%$ sodium dodecyl sulfate and $10 \mathrm{mM}$ sodium borate. Aliquots of the medium containing dissolved cells were assayed for radioactivity in a liquid scintillation spectrometer (model 3330, Packard Instrument Co., Inc., Downers Grove, IL) and for protein content (26).

The rate of monovalent cation transport was estimated by measurement of ${ }^{42} \mathrm{~K}$-uptake. Coverslips with attached monolayers of cells were similarly immersed in bicarbonate buffer solution (pH 7.35) containing $4 \mathrm{mM} \mathrm{K}^{+}$and a tracer quantity of ${ }^{42} \mathrm{~K}(5 \mu \mathrm{Ci} / \mathrm{ml})$ with or without $1 \mathrm{mM}$ ouabain. Specific ${ }^{42} \mathrm{~K}$-uptake was calculated as the difference between values obtained in the presence and absence of 1 $\mathrm{mM}$ ouabain. The initial rate of ${ }^{42} \mathrm{~K}$-uptake was determined similarly following a 10 -min preexposure of cells to medium containing zero $\mathbf{K}^{+}$.

Cell density correction. To normalize for cell density on each culture dish or coverslip, the monolayers were incubated in either $\mathrm{L}-\left[\mathrm{U}-{ }^{14} \mathrm{C}\right]$ leucine $(0.05 \mu \mathrm{Ci} / \mathrm{ml})$ or $\mathrm{L}-\left[4,5-{ }^{3} \mathrm{H}(\mathrm{N})\right]$ leucine $(0.1 \mu \mathrm{Ci} / \mathrm{ml})$ for $24 \mathrm{~h}$ before each experiment. $\left[{ }^{14} \mathrm{C}\right]$ leucine or $\left[{ }^{3} \mathrm{H}\right]$ leucine was incorporated into the cell protein and the ${ }^{14} \mathrm{C}$ - or ${ }^{3} \mathrm{H}$-counts permitted 
estimation of cell density on each culture dish or glass coverslip, respectively. The relationship between radioactive counts and protein concentration (26) allowed accurate estimation of protein concentration in each culture dish or glass coverslip. Thus, simultaneous counting of ${ }^{3} \mathrm{H}$ and ${ }^{24} \mathrm{Na}$, or ${ }^{14} \mathrm{C}$ and ${ }^{3} \mathrm{H}$ permitted normalization of sodium content or $\left[{ }^{3} \mathrm{H}\right]$ ouabain binding per milligram cell protein.

Miscellaneous. Protein concentration was assayed by the method of Lowry et al. (26) using crystalline bovine serum albumin as standard. Hanks' salt solution, M199, and fetal calf serum were purchased from Gibco Laboratories, Grand Island, NY. $\left[{ }^{3} \mathrm{H}\right]$ ouabain and ${ }^{24} \mathrm{NaCl}$ were purchased from New England Nuclear, Boston, MA. Insulin, transferrin, and $T_{3}$ were purchased from Sigma Chemical Co., St. Louis, MO. Selenium (Spectrapure) was purchased from United Mineral and Chemical Corp., NY. All other chemicals used were of the highest grade commercially available. All solutions were sterilized by filtering through Nalgene sterilization filters (pore size, $0.45 \mu \mathrm{m}$; Nalge Co., Rochester, NY). Insulin containing solutions were filtered through Millex-GV filter (pore size, $0.22 \mu \mathrm{m}$; Millipore Corp., Bedford, MA).

Statistical analyses were performed using Student's $t$ test and twoway analysis of variance.

\section{Results}

$\left[{ }^{3} \mathrm{H}\right]$ ouabain binding. Fig. 1 shows the binding of $10^{-7} \mathrm{M}$ $\left[{ }^{3} \mathrm{H}\right]$ ouabain to intact cells grown in serum-free medium containing either zero or $10^{-8} \mathrm{M} \mathrm{T}_{3}$. In both types of cells, the specific $\left[{ }^{3} \mathrm{H}\right.$ ]ouabain binding was rapid and reached a steady state within $10 \mathrm{~min}$. Specific $\left[{ }^{3} \mathrm{H}\right]$ ouabain binding followed pseudo first order kinetics with an association rate constant of $2.8 \times 10^{6} \mathrm{M}^{-1} \mathrm{~min}^{-1}$ both in cells grown in zero and in $10^{-8} \mathrm{M} \mathrm{T}_{3}$, indicating that the kinetic characteristics of $\left[{ }^{3} \mathrm{H}\right]$ ouabain binding to intact cultured heart cells are not affected by thyroid hormone in $\mathrm{K}^{+}$-free medium. The steady state level of $\left[{ }^{3} \mathrm{H}\right]$ ouabain binding was increased, however, by growth in $10^{-8} \mathrm{M} \mathrm{T}_{3}$ from $1.67 \pm 0.27$ to $2.57 \pm 0.26 \mathrm{pmol} / \mathrm{mg}$ protein $(P<0.05)$.

To examine the effect of $T_{3}$ concentration in growth media on the total number of sodium pump sites in the sarcolemmal

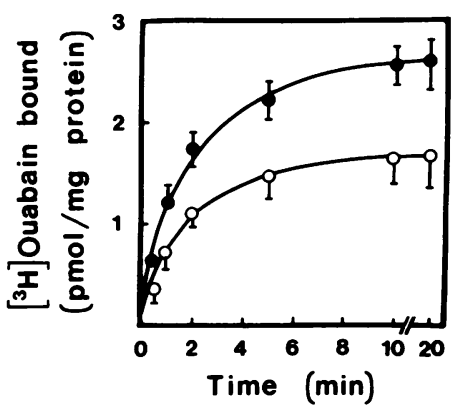

Figure 1. Time-dependency of $\left[{ }^{3} \mathrm{H}\right]$ ouabain binding in $\mathrm{K}^{+}$-free medium. Cultured heart cells from 10 -d-old chick embryos were grown in serum-containing culture medium for $48 \mathrm{~h}$, and subsequently, grown in serum-free medium containing either zero (open circles) or $10^{-8} \mathrm{M}$ $T_{3}$ (filled circles) for another $48 \mathrm{~h}$. Cells were exposed to

$10^{-7} \mathrm{M}\left[{ }^{3} \mathrm{H}\right]$ ouabain for $0.5-20 \mathrm{~min}$. Cells were then filtered, washed, and dissolved, and the amount of $\left[{ }^{3} \mathrm{H}\right]$ ouabain bound was estimated from the radioactivity present on the filter. Specific binding, the difference in values obtained in the presence and absence of $1 \mathrm{mM}$ nonlabeled ouabain, is plotted. Each point is the mean of five determinations. Vertical lines are \pm 1 SEM. membrane, cultured chick ventricular cells were incubated to equilibrium with concentrations of $\left[{ }^{3} \mathrm{H}\right]$ ouabain ranging from 0.06 to $1.0 \mu \mathrm{M}$, and specifically bound $\left[{ }^{3} \mathrm{H}\right]$ ouabain was determined. Fig. 2 shows the concentration dependency of specific $\left[{ }^{3} \mathrm{H}\right]$ ouabain binding in $\mathrm{K}^{+}$-free medium in cells grown for $48 \mathrm{~h}$ in medium containing $10^{-10} \mathrm{M} \mathrm{T}_{3}$. The binding data indicate that near saturation of ouabain binding sites occurs with $1 \mu \mathrm{M}\left[{ }^{3} \mathrm{H}\right]$ ouabain. Therefore, the total number of sodium pump sites in the cell membrane was determined by assaying the amount of $\left[{ }^{3} \mathrm{H}\right]$ ouabain bound following incubation of cells to equilibrium in $1 \mu \mathrm{M}\left[{ }^{3} \mathrm{H}\right]$ ouabain.

To determine the number of sodium pump sites maintained in the absence of $T_{3}$ in the growth medium, cells were grown in serum-containing culture medium for $48 \mathrm{~h}$ and subsequently grown for several days in serum-free medium containing no added $T_{3}$. The total number of $\left[{ }^{3} \mathrm{H}\right]$ ouabain binding sites gradually declined to a new steady state level on the third day of growth in $\mathrm{T}_{3}$-free, serum-free medium and remained at this level for another $48 \mathrm{~h}$. As shown in Fig. 3, the total number of sodium pump sites under these conditions was $\sim 80 \%$ of the initial value observed just before the replacement of the culture medium by serum-free medium.

As shown in Fig. 1, growth in $T_{3}$ elevates the number of sodium pump sites in the sarcolemmal membrane. To determine whether this is a concentration-dependent phenomenon, we studied the effects of graded concentrations of $T_{3}$ in the serum-free culture medium on the total number of sodium pump sites. Growth of cells in $T_{3}$ concentrations from $10^{-10}$ to $10^{-7} \mathrm{M}$ for $48 \mathrm{~h}$ caused induction of additional sodium pump sites in the sarcolemmal membrane (Fig. 4). This effect was concentration-dependent. Increasing concentrations of $T_{3}$ to $10^{-8} \mathrm{M}$ were associated with increasing numbers of sodium pump sites. The peak level of sodium pump sites was produced by $10^{-8} \mathrm{M} \mathrm{T}_{3}$ and beyond that, the number of sodium pump sites decreased again. This was probably due to toxic effects of $10^{-7} \mathrm{M} \mathrm{T}_{3}$ as indicated by altered cell morphology including the presence of large cytoplasmic vacuoles, unresponsiveness to positive inotropic agents such as ouabain or isoproterenol,

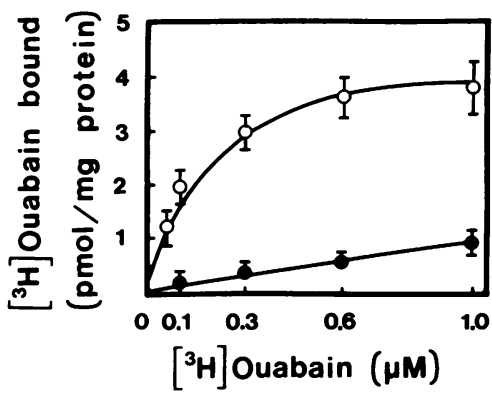

Figure 2. Concentration-dependency of $\left[{ }^{3} \mathrm{H}\right]$ ouabain binding in $\mathrm{K}^{+}$-free medium. Cells were grown in serum-free medium containing $10^{-10} \mathrm{M} \mathrm{T}_{3}$ for 48 $h$, then exposed to various concentrations of [ ${ }^{3} \mathrm{H}$ ]ouabain $(0.06-1.0 \mu \mathrm{M})$ for $20 \mathrm{~min}$ at $37^{\circ} \mathrm{C}$. Cells were then filtered, washed and dissolved, and radioactivity on the filter was assayed to determine bound $\left[{ }^{3} \mathrm{H}\right]$ ouabain. The amount of specifically bound $\left[{ }^{3} \mathrm{H}\right]$ ouabain (open circles) is the difference between total binding and that observed in the presence of 1 $\mathrm{mM}$ nonlabeled ouabain (filled circles). Each point in the mean of six determinations. Vertical lines indicate \pm 1 SEM. 


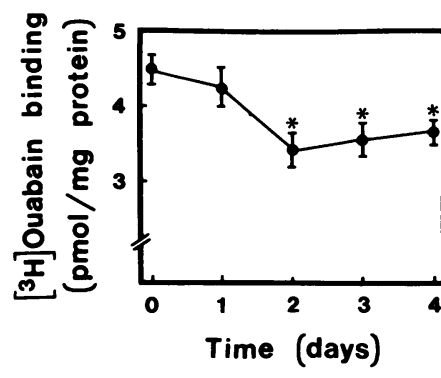

days. At each day, the total number of ouabain binding sites was determined by incubating the cells with $10^{-6} \mathrm{M}\left[{ }^{3} \mathrm{H}\right]$ ouabain and assaying for specific $\left[{ }^{3} \mathrm{H}\right]$ ouabain binding. Each point and vertical line represent mean $\pm \mathrm{SE}$ of six determinations. *Significantly different from the value observed at day $0(P<0.05)$.

and a marked reduction in the number of spontaneously contracting cells. Cells grown in medium containing $10^{-8} \mathrm{M}$ or lower concentrations of $\mathrm{T}_{3}$ did not show any such signs of toxicity. Synchronous contraction of normal frequency (100140 beats/min) were present in at least $80 \%$ of cells on the plate.

Since $T_{3}$ might in principle modify the growth rate, cell volume, and protein content of cultured chick ventricular cells, the number of sodium pump sites expressed per milligram protein might not reflect the change in sites per cell. To clarify this issue, identical numbers of cells were plated as previously described. After $48 \mathrm{~h}$ of growth in serum-containing medium, incubation was continued in serum-free media containing either $10^{-8} \mathrm{M}$ or zero $\mathrm{T}_{3}$. After $48 \mathrm{~h}$, cells were suspended by gentle trypsinization and numbers of cells and protein content per plate were determined. $T_{3}$ did not significantly alter either the number of cells or protein content per plate. The mean cell numbers per plate $(n=20)$ were $557,000 \pm 11,000$ and $591,000 \pm 15,000$, and mean protein contents per plate were $1.05 \pm 0.04$ and $1.06 \pm 0.03 \mathrm{mg}$ in cells exposed to $10^{-8} \mathrm{M}$ and zero $T_{3}$, respectively. In cells grown in $10^{-10} \mathrm{M} \mathrm{T}_{3}$, the density of sodium pump sites was $\sim 3.7 \times 10^{6}$ sites per cell. Others have reported values of $8 \times 10^{5}$ sites per cell in HeLa cells

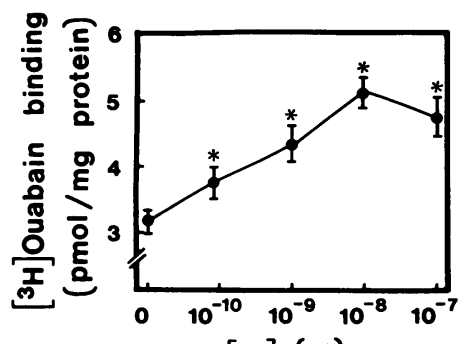

$\left[\mathrm{T}_{3}\right](\mathrm{M})$
Figure 4. Effects of growth of cells in graded concentrations of $T_{3}$ on the number of ouabain binding sites. Following growth of cells in serum-containing medium for $48 \mathrm{~h}$, medium was replaced with a serumfree medium containing 0 , $10^{-10}, 10^{-9}, 10^{-8}$, or $10^{-7}$ $M T_{3}$ and cells were allowed to grow for another

$48 \mathrm{~h}$. The total number of ouabain binding sites in the cell membrane was then determined as above. Each point and vertical line represent mean $\pm \mathrm{SE}$ of six determinations. *Significantly different from the value observed with zero $T_{3}(P<0.05)$.
(25) and $1.6 \times 10^{6}$ sites per cell in cultured rat heart cells (24). These results indicate that the number of ouabain binding sites expressed per milligram protein permits a valid comparison under our experimental conditions.

The possibility that growth in $T_{3}$ altered the affinity of NaK-ATPase for ouabain was next examined. As indicated by the parallel slopes in the Scatchard plots of $\left[{ }^{3} \mathrm{H}\right]$ ouabain binding data obtained with cells grown in medium containing $10^{-10}$ or $10^{-8} \mathrm{M} \mathrm{T}_{3}$ (Fig. 5), the change in the number of $\left[{ }^{3} \mathrm{H}\right]$ ouabain binding sites produced by $\mathrm{T}_{3}$ exposure was not due to altered affinity of these sites to ouabain. These results indicate that $T_{3}$ concentrations spanning the physiologic range modulate the number of sodium pump sites in the sarcolemmal membrane of cultured chick ventricular cells.

Intracellular sodium content. The effect of $\mathrm{T}_{3}$ concentration in growth media on intracellular sodium content was examined to determine the functional role of the additional sodium pump sites in the sarcolemmal membrane. Cells grown for 48 $h$ in medium containing various concentrations of $T_{3}$ were incubated to asymptote in medium containing ${ }^{24} \mathrm{Na}^{+}$for 30 min and the cellular sodium content was determined. As shown in Fig. 6, increasing concentrations of $T_{3}$ in the culture medium caused graded reductions in intracellular sodium content. Mean cellular sodium contents in cells grown in $\mathrm{T}_{3^{-}}$ free medium and in cells grown in medium containing $10^{-8}$ $\mathrm{M} \mathrm{T}_{3}$ were $82.0 \pm 7.5$ and $68.5 \pm 4.6 \mathrm{nmol} / \mathrm{mg}$ protein, respectively, a $20 \%$ difference in sodium content. Cellular $\mathrm{Na}$ contents in cells grown in serum-free, $\mathrm{T}_{3}$-free medium for 48 and $72 \mathrm{~h}$ were $82.0 \pm 7.5$ and $80.8 \pm 8.6 \mathrm{nmol} / \mathrm{mg}$ protein, respectively, indicating that growth in serum-free medium alone had no significant effect on cellular $\mathrm{Na}$ content over this time period. For comparison, cells grown in the presence of conventional serum-containing media had a mean $\mathrm{Na}$ content of $80.6 \pm 5.2$ $\mathrm{nmol} / \mathrm{mg}$ protein. When cells were exposed to $1 \mu \mathrm{M}$ ouabain for $30 \mathrm{~min}$ at the end of $\mathbf{4 8} \mathrm{h}$ growth in media containing various $T_{3}$ concentrations and cellular sodium content was similarly determined, $\left[\mathrm{Na}^{+}\right]_{\mathrm{i}}$ increased by $\sim 40 \%$ in groups of cells grown in each concentration of $T_{3}$. Thus, growth in $T_{3}$ also produced concentration-dependent decreases in $\left[\mathrm{Na}^{+}\right]_{i}$ in

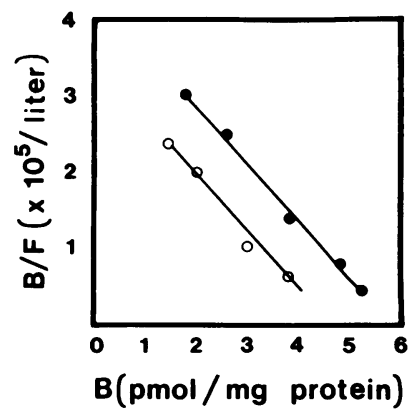

Figure 5. Scatchard plots of $\left[{ }^{3} \mathrm{H}\right]$ ouabain binding data. Cells were incubated with graded concentrations of $\left[{ }^{3} \mathrm{H}\right]$ ouabain in zero $\left[\mathrm{K}^{+}\right]_{0}$ medium for $20 \mathrm{~min}$ and $\left[{ }^{3} \mathrm{H}\right]$ ouabain bound to the cells was assayed. The specific $\left[{ }^{3} \mathrm{H}\right]$ ouabain binding, defined as the difference in binding observed in the presence and absence of $1 \mathrm{mM}$ nonlabeled ouabain, was used to calculate bound $(B)$ and free $(F)$ ouabain

Open circles and filled circles are plots of ouabain binding data observed in cells grown in medium containing $10^{-10}$ and $10^{-8} \mathrm{M} \mathrm{T}_{3}$, respectively. 


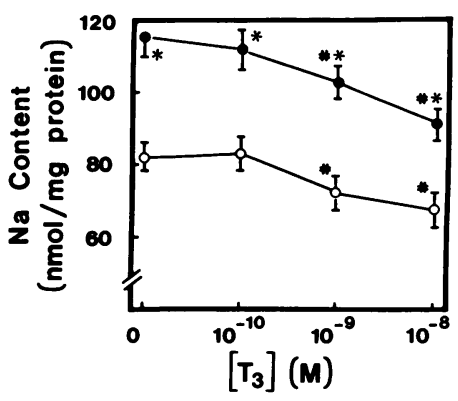

taining $1 \mu \mathrm{M}$ ouabain and ${ }^{24} \mathrm{Na}^{+}$for $30 \mathrm{~min}$ (filled circles). After washing briefly to remove extracellular ${ }^{24} \mathrm{Na}^{+}$, cells were dissolved and radioactivity in the cells was assayed. The sodium content was calculated for each coverslip and expressed as nanomoles per milligram protein. Each point and vertical line represent mean $\pm \mathrm{SE}$ of eight observations. *, Significantly different from the corresponding control values $(P<0.05)$. \#, Significantly different from the value observed in cells grown in $\mathrm{T}_{3}$-free medium within the same experimental group $(P<0.05)$.

the presence of $1 \mu \mathrm{M}$ ouabain. These observations indicate that the $T_{3}$ content of growth media controls intracellular sodium content by modulating the number of active sodium pump sites in the sarcolemmal membrane.

Contractility measurements. Given the known relationship between sodium pump inhibition and inotropic and toxic effects of cardiac glycosides $(17,22,27)$, one would predict that cells with higher numbers of active sodium pump sites would be less responsive and more tolerant to the effects of ouabain compared with cells with lower numbers of sodium pumps, assuming that the affinity of pump sites for ouabain did not change. To examine the effects of altered numbers of sodium pumps produced by growth of cells in varying concentrations of $T_{3}$ on the inotropic and toxic effects of cardiac glycosides, dose-response curves for ouabain were determined by measuring percent change in amplitude of cell motion using an optical-video system (19). For each cell, the maximal changes produced by a given concentration of ouabain were determined as the percent of change induced in the same cell by $3.6 \mathrm{mM}\left[\mathrm{Ca}^{++}\right]_{0}$, a concentration of $\mathrm{Ca}^{++}$that produced maximal increases in amplitude of cell motion in both $T_{3^{-}}$ deficient and $\mathrm{T}_{3}$-supplemented cells.

Over the range from 0.1 to $4 \mu \mathrm{M}$, increasing concentrations of ouabain produced graded positive inotropic effects in cultured heart cells. As shown in Fig. 7, for each concentration of ouabain, cells grown in $T_{3}$-free medium showed a significantly greater positive inotropic effect than cells grown in medium containing $10^{-8} \mathrm{M} \mathrm{T}_{3}$. Thus, the concentration-effect curve for ouabain was shifted to the right by growth of cells in high levels of $T_{3}$. The maximal positive inotropic effect in cells grown in $\mathrm{T}_{3}$-free medium was produced by $2 \mu \mathrm{M}$ ouabain, whereas that in cells grown in medium containing $10^{-8} \mathrm{M} \mathrm{T}_{3}$ occurred at $4 \mu \mathrm{M}$ ouabain. The maximal augmentation of inotropic state achieved in both types of cells was not signif-

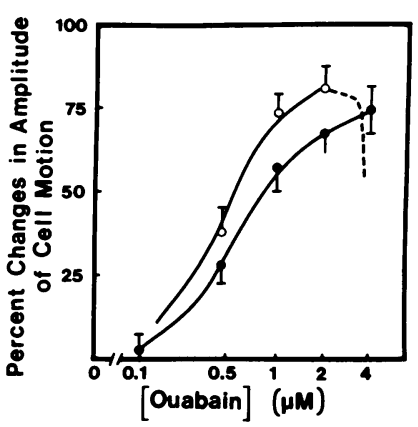

Figure 7. Effects of growth of cells in medium containing zero or $10^{-8} \mathrm{M} \mathrm{T}_{3}$ on the concentration-effect relation for ouabain. See legend to Fig. 2 for growth conditions. Contractile responses of cells to several concentrations of ouabain $(0.1-4 \mu \mathrm{M})$ were determined using the optical-video system. The responses of a single cell to ouabain are expressed as percentages of the response of that same cell to $3.6 \mathrm{mM} \mathrm{Ca}^{++}$. Open circles and filled circles represent responses of cells grown in medium containing 0 and $10^{-8} \mathrm{M} \mathrm{T}_{3}$, respectively. Dotted line represents the development of toxicity.

cantly different. For each type of cell, higher concentrations of ouabain than those which produced maximal positive inotropic effects were toxic as manifested by a marked negative inotropic effect, spontaneous arrhythmic contractions, and/or a concomitant shift in resting base line (contracture). Thus, these results show that sensitivity of cardiac myocytes to positive inotropic and toxic effects of ouabain is a function of the concentration of thyroid hormone in which the cells are grown.

\section{Discussion}

Sensitivity of the heart to digitalis glycosides in vivo depends in part on the thyroid state, since hyperthyroidism is associated with increased tolerance to cardiac glycosides and hypothyroidism with decreased tolerance (1-3). The results of the present study show that a direct effect of thyroid hormone on cultured cardiac myocytes significantly alters responsiveness to cardiac glycosides. Specifically, the effects of thyroid hormone on the sarcolemmal NaK-ATPase and the resulting changes in ion transport across the cell membrane appear to be important mechanisms responsible for the dependence of digitalis' action on thyroid status.

The effects of thyroid hormone in increasing membrane NaK-ATPase have been well documented in a variety of species and tissues with respect to both enzyme activity $(9,11$, $28,29)$ and the number of sodium pump sites as judged by ouabain binding $(12,1315,28)$. In cultured chick ventricular cells, $T_{3}$ also caused an elevation of sodium pump sites in the sarcolemmal membrane in a concentration-dependent manner. A maximal increase to $160 \%$ of the control number of sodium pump sites was produced by growing the cells in medium containing $10^{-8} \mathrm{M} \mathrm{T}_{3}$ for a period of $48 \mathrm{~h}$. It has been reported that the half-life of $T_{3}$ in hepatocyte cultures containing serum is $3.5 \mathrm{~h} \mathrm{(29).} \mathrm{Therefore,} \mathrm{it} \mathrm{is} \mathrm{possible} \mathrm{that} \mathrm{this} \mathrm{concentration}$ of $\mathrm{T}_{3}\left(10^{-8} \mathrm{M}\right)$ did not maximally stimulate NaK-ATPase induction due to metabolism of $T_{3}$. However, our finding that a higher $T_{3}$ concentration $\left(10^{-7} \mathrm{M}\right)$ was toxic to the cells, and the fact that the culture medium was serum free, which may 
prolong the half-life of $T_{3}$, suggest that the 1.6-fold increase in the number of sodium pump sites is near maximal under the present experimental conditions. The exact mechanism of this induction process is not known, although the studies of Lo and Edelman (30) and Lo and Lo (31) indicate that the increase in sodium pump site density in renal cortex is due to an increase in synthesis rate rather than a change in degradation rate of pump sites.

The initial rates of specific (i.e., ouabain-sensitive) ${ }^{42} \mathrm{~K}$ uptake into cells loaded with $\mathrm{Na}$ by 15 -min preincubation in zero $\mathrm{K}^{+}$medium were $102 \pm 5$ and $71 \pm 4 \mathrm{nmol} / \mathrm{mg}$ protein per min in $\mathrm{T}_{3}$-treated $\left(10^{-8} \mathrm{M}\right)$ and untreated cells, respectively, indicating a $44 \%$ increase in maximal sodium pump activity in cells grown in $10^{-8} \mathrm{M} \mathrm{T}_{3}$. This suggests that the increase in the number of ouabain binding sites is roughly proportional to the increase in maximal monovalent cation active transport activity. ${ }^{42} \mathrm{~K}$-uptake studies with cultured heart cells not loaded with $\mathrm{Na}^{+}$prior to ${ }^{42} \mathrm{~K}$-uptake measurements showed that cells grown in $10^{-8} \mathrm{M} \mathrm{T}_{3}$ as compared with zero $\mathrm{T}_{3}$ had a $26 \%$ greater monovalent cation active transport activity $(26.7 \pm 1.1$ vs. $21.3 \pm 0.9 \mathrm{nmol} / \mathrm{mg}$ protein per $\mathrm{min}$ ). This is likely related, at least in part, to the $20 \%$ increase in beating rate of cells grown in the presence of $10^{-8} \mathrm{M} \mathrm{T}_{3}$ (see below). Since the number of ouabain binding sites was increased 1.6-fold by growth in $10^{-8} \mathrm{M} \mathrm{T}_{3}$ under identical conditions, the turnover rate of individual sodium pumps in $\mathrm{T}_{3}$-treated cells was $\sim 80 \%$ of that in cells grown in the absence of $T_{3}$. However, the total monovalent cation transport per cell was clearly elevated and our finding that growth of cells in medium containing high concentrations of $\mathrm{T}_{3}$ was associated with lower intracellular sodium content indicates that the additional pump sites induced by $T_{3}$ are indeed functional and contribute to the lowering of intracellular sodium content. Similar results have been observed in rat diaphragm and rat heart (32), although contrasting results have also been reported for mouse diaphragm muscle in which $T_{3}$ was found to have no effect on intracellular $\mathrm{Na}^{+}$or $\mathrm{K}^{+}$-content (33) and for rat erythrocytes in which $\mathrm{T}_{3}$ produced inconsistent changes in intracellular $\mathrm{Na}^{+}$concentration (32). The reasons for these differing results are not clear, but may be due to the species difference or to differing experimental techniques.

A concentration of ouabain $(1 \mu \mathrm{M})$ that causes a positive inotropic effect without evidence of toxicity $(20,21)$ elevated $\left[\mathrm{Na}^{+}\right]_{i}$ by $\sim 40 \%$ in all cells included in the present study, irrespective of the $T_{3}$ level in growth media. Hence, as shown in Fig. 6, the response to thyroid hormone was a concentrationdependent decrease in steady-state $\left[\mathrm{Na}^{+}\right]_{\mathrm{i}}$ in the presence of 1 $\mu \mathrm{M}$ ouabain. These ouabain-induced changes in intracellular sodium were associated with altered responses of the cell to ouabain. Cells grown in medium containing $10^{-8} \mathrm{M} \mathrm{T}_{3}$ were inotropically less responsive to ouabain than cells grown in $\mathrm{T}_{3}$-free medium (Fig. 7). In cells grown in medium containing an intermediate range of concentrations of $T_{3}$, the inotropic responsiveness to ouabain was also intermediate. Furthermore, the cells exhibited a greater tolerance to toxic effects of ouabain when the concentration of $T_{3}$ was increased in the culture medium. Thus, the most straightforward interpretation of our findings is that cells with increased numbers of sodium pump sites in response to growth in $10^{-8} \mathrm{M} \mathrm{T}_{3}$ have altered sensitivity to the inotropic and toxic effects of cardiac glycosides as a result of reduced intracellular sodium levels at any given cardiac glycoside concentration.

In addition to causing changes in the number of sodium pump sites and $\left[\mathrm{Na}^{+}\right]_{i}$, growth in $\mathrm{T}_{3}$ augmented the spontaneous contraction rate of the cultured heart cells. In cells grown in medium containing no $T_{3}$ or $10^{-8} \mathrm{M} \mathrm{T}_{3}$, the frequency of spontaneous contractions was $108 \pm 2.4$ or $124 \pm 4.0 / \mathrm{min}$ $(n=10)$, respectively, indicating significant $\mathrm{T}_{3}$-induced changes in the electrophysiology of the cells. In addition to common clinical experience with thyrotoxic patients, similar findings have been reported in animals in which thyroid hormone treatment was associated with a faster rate of beating in isolated rabbit atria and intact dog heart (34). These alterations in beating rate, however, are unlikely to invalidate our interpretation of the mechanism of $T_{3}$-induced change in digitalis tolerance in myocardial cells because the peak positive inotropic effect of glycosides has been shown to be either independent of (35-37) or enhanced by increases in frequency of stimulation (38-39) over this range.

The results reported here support the proposed mechanism of action of cardiac glycosides $(17,20,22,40)$ in which inhibition of sodium pump activity is thought to be followed by elevation of intracellular sodium and consequent augmentation of cellular calcium content via sodium-calcium exchange. Our results appear to be inconsistent with the alternative proposal that binding of digitalis to NaK-ATPase causes the release of calcium from enzyme-associated sarcolemmal sites (41-44). A lesser rather than greater inotropic response to a given ouabain concentration was observed in cells with increased numbers of sodium pump sites, despite the fact that a greater absolute number of NaK-ATPase sites would be occupied because of the unchanged affinity of sites for ouabain (Fig. 5).

In an in vivo situation, changes in sensitivity to digitalis of cardiac tissue may be further modified by $T_{3}$-induced alterations in the tissue responsiveness to catecholamines or insulin levels in the circulation, since both of the latter hormones are known to affect sodium pump activity. Therefore, additional studies are clearly required to elucidate the effects of interactions of hormones on digitalis sensitivity in vivo.

In conclusion, growth in the presence of $T_{3}$ caused a concentration-dependent elevation of the total number of functional sodium pump sites in the sarcolemmal membrane of cultured chick ventricular cells. The increase in sodium pump sites was associated with a decrease in cellular sodium content, and with reduced positive inotropic and toxic responses to ouabain. These changes appear to occur as a result of active extrusion of intracellular sodium by the additional sodium 
pumps, and consequently, reduced calcium uptake via sodiumcalcium exchange $(16,17,27,34)$. Altered tolerance to cardiac glycosides in clinical states of hypothyroidism or hyperthyroidism may be explained, at least in part, by this mechanism.

\section{Acknowledgments}

Dr. Kim is a recipient of a postdoctoral fellowship HL06630. This work was supported in part by U. S. Public Health Service grant HL18003.

\section{References}

1. Frye, R. L., and E. Braunwald. 1961. Studies on digitalis. The influence of triiodothyronine on digitalis requirements. Circulation. 23:376-382.

2. Morrow, D. H., T. E. Gaffney, and E. Braunwald. 1963. Studies on digitalis: influence of hyper- and hypothyroidism on the myocardial response to ouabain. J. Pharmacol. Exp. Ther. 14:324-328.

3. Buccino, R. A., J. F. Spann, Jr., P. E. Pool, E. H., Sonnenblick, and $E$. Braunwald. 1967. Influence of the thyroid state on the intrinsic contractile properties and energy stores of the myocardium. J. Clin. Invest. 46:1669-1682.

4. Doherty, J. E., and W. H. Perkins. 1962. Studies with tritiated digoxin in human subjects after intravenous administration. Am. Heart J. 63:528-537.

5. Eickenbusch, W., H. Lahrtz, U. Seppelt, and P. A. van Zwieten. 1970. Serum concentration and urinary excretion of ${ }^{3} \mathrm{H}$-ouabain and ${ }^{3} \mathrm{H}$-digitoxin in patients suffering from hyperthyroidism or hypothyroidism. Klin. Wochenschr. 48:270-275.

6. Croxson, M. S., and H. K. Ibbertson. 1975. Serum digoxin in patients with thyroid disease. Br. Med. J. 3:566-568.

7. Shenfield, G. J., J. Thompson, and D. B. Horn. 1977. Plasma and urinary digoxin in thyroid dysfunction. Europ. J. Clin. Pharmacol. 12:437-444.

8. Kokenge, F., S. Jost, and K. D. Kolenda. 1978. Serumspiegeluntersuchungen von Digoxin und Digitoxin an Patienten mit Schilddrüsenfunktionsstörungen. Kongresbericht d. 91. Tagung der Nordwestdeutschen. Ges. Inn. Med. 23.

9. Ismael-Beigi, F., and I. S. Edelman. 1971. The mechanism of the calorigenic action of thyroid hormone: stimulation of $\mathrm{Na}^{+}$and $\mathrm{K}^{+}$activated adenosine triphosphatase activity. J. Gen. Physiol. 57:710722.

10. Philipson, K. D., and I. S. Edelman. 1977. Thyroid hormone control of $\mathrm{Na}^{+}-\mathrm{K}^{+}$-ATPase and $\mathrm{K}^{+}$-dependent phosphatase in rat heart. Am. J. Physiol. 232:C196-C201.

11. McDermott, P., and I. Klein. 1983. Effect of thyroid hormone on cultured rat heart cells. Clin. Res. 31:205A.

12. Edelman, I. S. 1974. Thyroid thermogenesis. N. Engl. J. Med. 290:1303-1308.

13. Curfman, G. D., T. J. Crowley, and T. W. Smith. 1977. Thyroid-induced alterations in myocardial sodium- and potassiumactivated adenosine triphosphatase, monovalent cation active transport, and cardiac glycoside binding. J. Clin. Invest. 59:586-590.

14. Hegyvary, C. 1977. Alterations of cardiac NaK-ATPase by the thyroid state in the rat. Res. Commun. Chem. Pathol. Pharmacol. 17:689-702.

15. Lin, M. H., and T. Akera. 1978. Increased $\mathrm{Na}^{+}, \mathrm{K}^{+}$-ATPase concentration in various tissues of rats caused by thyroid hormone treatment. J. Biol. Chem. 253:723-726.

16. Reuter, H., and H. Seitz. 1968. The dependence of calcium efflux from cardiac muscle on temperature and external ion composition. J. Physiol. 195:451-470.

17. Langer, G. A. 1977. Relationship between myocardial contractility and effects of digitalis on ionic exchange. Fed. Proc. 36:22312234.

18. Horackova, M., and G. Vassort. 1979. Sodium-calcium exchange in regulation of cardiac contractility. Evidence for an electrogenic, voltage-dependent mechanism. J. Gen. Physiol. 73:403-424.

19. Barry, W. H., and T. W. Smith. 1982. Mechanisms of transmembrane calcium movements in cultured chick embryo ventricular cells. J. Physiol. (Lond.). 325:243-260.

20. Biedert, S., W. H. Barry, and T. W. Smith. 1979. Inotropic effects and changes in sodium and calcium contents associated with inhibition of monovalent cation transport by ouabain in cultured myocardial cells. J. Gen. Physiol. 74:479-494.

21. Barry, W. H., S. Biedert, D. S. Miura, and T. W. Smith. 1981. Changes in cellular $\mathrm{Na}^{+}, \mathrm{K}^{+}$, and $\mathrm{Ca}^{++}$contents, monovalent cation transport rate and contractile state during washout of cardiac glycosides from cultured chick heart cells. Circ. Res. 49:141-149.

22. Akera, T., and T. M. Brody. 1978. The role of $\mathrm{Na}^{+}, \mathrm{K}^{+}$ ATPase in the inotropic action of digitalis. Pharmacol. Rev. 29:187220.

23. Libby, P. 1983. Culture of contractile mammalian heart cells in defined serum-free medium that limits non-muscle cell proliferation. Clin. Res. 31:201A.

24. McCall, D. 1979. Cation exchange and glycoside binding in cultured rat heart cells. Am. J. Physiol. 236:C87-C95.

25. Aiton, J. F., J. F. Lamb, and P. Ogden. 1981. Down-regulation of the sodium pump following chronic exposure of HeLa cells and chick embryo heart cells to ouabain. Br. J. Pharmacol. 73:333-340.

26. Lowry, O. H., N. J. Rosebrough, A. L. Farr, and R. J. Randall. 1951. Protein measurement with the Folin phenol reagent. J. Biol. Chem. 193:265-275.

27. Smith, T. W., and W. H. Barry. 1983. Monovalent cation transport and mechanisms of digitalis-induced inotropy. Curr. Top. Membr. Transp. 19:857-884.

28. Lo, C.-S., T. R. August, V. A. Liberman, and I. S. Edelman. 1976. Dependence of renal $\left(\mathrm{Na}^{+}+\mathrm{K}^{+}\right)$-adenosine triphosphatase activity on thyroid status. J. Biol. Chem. 251:7826-7833.

29. Ismael-Beigi, F., D. M. Bissel, and I. S. Edelman. 1979. Thyroid thermogenesis in adult rat hepatocytes in primary monolayer culture. J. Gen. Physiol. 73:369-383.

30. Lo, C.-S., and I. S. Edelman. 1976. Effect of triiodothyronine on the synthesis and degradation of renal cortical $\left(\mathrm{Na}^{+}, \mathrm{K}^{+}\right)$-adenosine triphosphatase. J. Biol. Chem. 251:7834-7840.

31. Lo, C.-S., and T. N. Lo. 1980. Effect of triiodothyronine on the synthesis and degradation of the small subunit of renal cortical $\left(\mathrm{Na}^{+}+\mathrm{K}^{+}\right)$-adenosine triphosphate. J. Biol. Chem. 255:2131-2136.

32. Ismael-Beigi, F., and I. S. Edelman. 1973. Effects of thyroid status on electrolyte distribution in rat tissues. Am. J. Physiol. 225:11721177.

33. Biron, R., A. Burger, A. Chinet, T. Clausen, and R. DuboisFerriere. 1979. Thyroid hormones and the energetics of active sodiumpotassium transport in mammalian skeletal muscle. J. Physiol. 297:4760. 
34. Freedberg, A. S., and M. W. Hamolsky. 1974. Effects of thyroid hormones on certain nonendocrine organ systems. Handb. Physiol. 3(sect. 7):435-468.

35. Koch-Weser, J., and J. R. Blinks. 1962. Analysis of the relation of the positive inotropic action of cardiac glycosides to the frequency of contraction of the heart muscle. J. Pharmacol. Exp. Ther. 136:305317.

36. Koch-Weser, J. 1971. Myocardial contraction frequency and onset of cardiac glycoside action. Circ. Res. 28:34-48.

37. Temma, K., and T. Akera. 1982. Enhancement of cardiac actions of ouabain and its binding to $\mathrm{Na}^{+}, \mathrm{K}^{+}$-adenosine triphosphatase by increased sodium influx in isolated guinea-pig heart. J. Pharmacol. Exp. Ther. 223:490-496.

38. Reiter, M., and F. Strobl. 1972. Contraction frequency and concentration in the positive inotropic effect of a cardioactive steroid on ventricular muscle. J. Pharmacol. 3:550.

39. Ebner, F., and M. Reiter. 1977. The dependence of contraction frequency of the positive inotropic effect of dihydro-ouabain. NaunynSchmiedeberg's Arch. Pharmacol. 300:1-9.

40. Kazazoglou, T., J. F. Renaud, B. Rossi, and M. Lazdunski.
1983. Two classes of receptors in chick ventricular cardiac cells and their relation to $\left(\mathrm{Na}^{+}, \mathrm{K}^{+}\right)$-ATPase inhibition, intracellular $\mathrm{Na}^{+}$accumulation, $\mathrm{Ca}^{2+}$ influx, and cardiotonic effect. J. Biol. Chem. 258:1216312170.

41. Lüllmann, H., and T. Peters. 1979. Action of cardiac glycosides on the excitation-contraction coupling in heart muscle. Prog. Pharmacol. 2:1-57.

42. Peters, T., R. H. Raben, and O. Wasserman. 1974. Evidence for a dissociation between positive inotropic effect and inhibition of the $\mathrm{Na}, \mathrm{K}-\mathrm{ATPase}$ by ouabain, cassaine and their alkylating derivatives. Eur. J. Pharmacol. 26:166-174.

43. Lüllmann, H., R. Weber, and P. A. van Zwieten. 1969. The correlation between the decline of the positive inotropic effect and the loss of cardiac glycosides from isolated atria during washout. Eur. J. Pharmacol. 6:235-240.

44. Gervais, A., L. K. Lane, B. M. Anner, G. E. Lindenmayer, and A. Schwartz. 1977. A possible molecular mechanism of the action of digitalis: ouabain action on calcium binding to sites associated with a purified Na-K activated ATPase from the kidney. Circ. Res. 40:814. 